\title{
In situ benthic oxygen fluxes in a nearshore coastal marine system: a new approach to quantify the effect of wave action
}

\author{
Daniel E. Malan ${ }^{1}$, Anton McLachlan ${ }^{2}$ \\ ${ }^{1}$ Cape Provincial Administration, Chief Directorate Nature and Environmental Conservation, Coastal Management Unit, \\ Private Bag X6546, George 6530, South Africa \\ ${ }^{2}$ Zoology Department and Institute for Coastal Research, University of Port Elizabeth, PO Box 1600, Port Elizabeth 6000 , \\ South Africa
}

\begin{abstract}
A simple benthic chamber, with a flexible membrane to allow for wave-induced interstitial water flow, is described. The membrane has a low permeability to oxygen, compared to other materials previously employed in chamber studies. Polyethylene and latex rubber (condoms) are highly permeable to oxygen and clearly unsuitable for oxygen-related studies. Glass syringes tested for oxygen permeability were far superior to plastic syringes, the latter being completely inappropriate even in short-term studies. A study at Kings Beach, South Africa, using chambers with flexible membranes showed that oxygen consumption was significantly higher in chambers with flexible tops $(p<0.005)$ than in chambers with solid tops. The difference in the respectuve fluxes $[18.5 \pm 2.7(95 \% \mathrm{CI})$ compared to $10.7 \pm 4.6 \mathrm{ml} \mathrm{O}_{2} \mathrm{~m}^{-2} \mathrm{~h}^{-1}$ ] was positively correlated with the effect of wave action at this medium energy exposed beach. Use of chambers with solid tops could result in underestimates in oxygen consumption of $>50 \%$ at the study site. It 15 concluded that wave action, with its resultant interstitial water flow, can significantly affect the oxygen consumption of shallow water sediments.
\end{abstract}

\section{INTRODUCTION}

Measurement of exchanges of dissolved compounds between sediments and overlying waters in high or medium energy environments is not a simple procedure. The passage of surface waves causes a fluctudtion of bottom hydrostatic pressures in shallow seas (Putnam \& Johson 1949, Carstens 1968, Steele et al. 1970), which induces water movement in permeable deposits (Putnam 1949, Webb \& Theodor 1968, 1972, Steele et al. 1970, Liu 1973, Swart \& Crowley 1983). The biological and chemical importance of this 'subtidal pump' has been described by several authors (Riedl et al. 1972, Rutgers van der Loeff 1981, McLachlan 1983). Further, turbulence induced by stirring in overlying water increases oxygen consumption of sediments (Carey 1967, Martin \& Bella 1971, James 1974, Davies 1975, Snodgrass \& Fay 1987)

Interference with the hydrodynamic environment is one of the main disadvantages of using in situ chambers to measure metabolism of, or flux of dissolved gases and nutrients across, the benthic boundary layer (Hale 1975 Hargrave \& Connolly 1978, Rutgers van der Loeff et al. 1981, Lindeboom et al. 1984). Clearly benthic oxygen consumption measurements should be made under conditions that mimic the natural water flow (Hale 1975, Gust 1977, Boynton et al. 1981). Despite the importance of water movement, the effects of wave action on benthic oxygen exchange have not been quantified in chamber studies of benthic metabolism.

The aim of this paper is 2 -fold. Firstly, to introduce a simple chamber that does not impair wave-induced water flow through the sea bed in shallow high energy systems. Secondly, to present preliminary data testing the hypothesis that this interstitial water flow alters the oxygen flux in this nearshore coastal marine system. A detailed investigation comparing oxygen consumption and production measured in situ using chambers with that of cores and theoretical fluxes is nearing completion, but is not reported on here. 


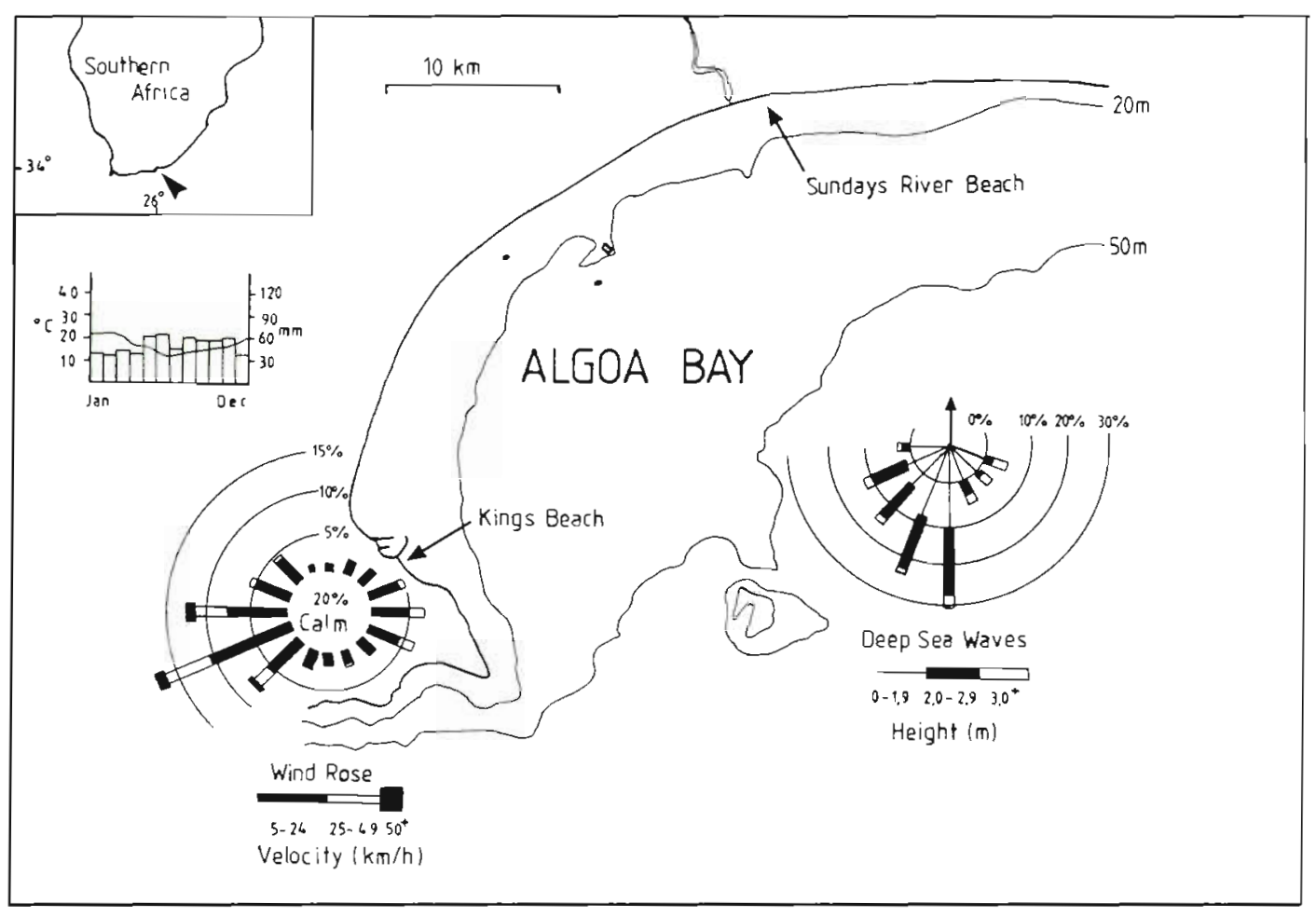

Fig. 1. Location of study site, showing wave and wind roses, temperature and rainfall near Kings Beach, South Africa (adapted from Beckley 1988)

\section{MATERIALS AND METHODS}

Study area. All sampling was conducted at Kings Beach $\left(33^{\circ} 58^{\prime} 25^{\prime \prime} \mathrm{S} ; 25^{\circ} 38^{\prime} 50^{\prime \prime} \mathrm{E}\right)$ in the corner of Algoa Bay, South Africa (Fig. 1). Kings Beach is the least exposed sandy beach near Port Elizabeth, but it nevertheless experiences continual wave action and may be considered medium energy by global standards. It is an exposed beach with a rating of 12.5 according to a 20-point exposure rating system suggested for sandy beaches (McLachlan 1980). Depending on weather conditions the surf zone extends out 50 to $100 \mathrm{~m}$, with an average breaker height of ca $1 \mathrm{~m}$. Mean spring tide range equals $1.65 \mathrm{~m}$ (McLachlan et al. 1984). Seasonal variations in sea water temperature can be considered mild, ranging maximally from 12 to $24^{\circ} \mathrm{C}$ (Beckley 1988).

Kings Beach has fine (average $\mathrm{Mz}=220 \mathrm{um}$ ) wellsorted sand with a high $\mathrm{CaCO}_{3}$ content (average $60 \%$ ) (Table 1). Organic matter and subsieves (the fraction passing through a $63 \mu \mathrm{m}$ sieve) average $2.2 \%$ and $2.7 \%$ respectively. The $\mathrm{pH}$ and oxygen saturation decrease with depth into the sediment, but no anoxic conditions are encountered to a depth of $60 \mathrm{~cm}$ (the greatest depth sampled) (Malan \& McLachlan 1985). These authors further showed that meiofaunal dry bio- mass averages $1119 \mathrm{mg} \mathrm{m}^{-2}$ with nematodes dominating and harpacticoid copepod numbers being low. Bacterial biomass averages $6197 \mathrm{mg} \mathrm{m}^{-2}$ and increases in an offshore direction. More information on this beach may be found in McLachlan et al. (1984) and Malan \& McLachlan (1985).

Oxygen permeability of plastic and glass syringes. Oxygen permeability was determined for $20 \mathrm{ml}$ plastic and glass syringes. Pure nitrogen was bubbled through filtered sea water $(0.2 \mu \mathrm{m}$ Nucleopore) to lower the oxygen content (Malan 1986) to ca $25 \mathrm{~mm}$ Hg. Triplicate sets of syringes were incubated in air-equilibrated sea water $\left(20^{\circ} \mathrm{C}, 35 \%\right)$ and oxygen content monitored over a $36 \mathrm{~h}$ period.

In a separate experiment triplicate glass syringes were filled with $0.2 \mu \mathrm{m}$ filtered sea water, unfiltered sea water and unfiltered sea water of low oxygen content (ca $25 \mathrm{~mm} \mathrm{Hg}$ ). The syringes were incubated under similar conditions to the above. Oxygen readings were periodically recorded on a Radiometer acid-base analyzer over $6 \mathrm{~h}$.

Oxygen permeability of volume compensation bags. Most authors use chambers of solid construction for measurement of benthic metabolism. It is therefore necessary to allow for some form of volume compensation to prevent interstitial water from flowing into the 
chamber during sample removal. Although most authors do not compensate for the volume of sample removed (Table 2), some authors have allowed water to enter from outside (Hallberg et al. 1972, Schippel et al. 1973, Propp et al. 1980, Hopkinson \& Wetzel 1982, Pregnall \& Miller 1988, Alongi et al. 1989, Jahnke \& Christiansen 1989), while others have employed collapsible bags (Hartwig 1976, Dyrssen et al. 1984 , Anderson et al. 1986, Dyrssen 1986) or a small 'expansion chamber' (Kelly 1984, Oviatt et al. 1984).

Condoms, polyethylene bags (Hartwig 1976, Klump and Martens 1981. Anderson et al. 1986) and a nylon/ polyethylene co-extrusion bag (see below) were evaluated as possible means of volume compensation. A number of bags were completely filled with $150 \mathrm{ml} \mathrm{low}$ oxygen content sea water, incubated in air-equilibrated sea water and oxygen content monitored.

Testing of flexible membranes. To allow for waveinduced pumping of water through the sediment a flexible membrane top chamber was designed. As this membrane had to be practically impermeable to oxygen, a co-extrusion consisting of a $45 \mu \mathrm{m}$ polyethylene layer, a $15 \mu \mathrm{m}$ bonding agent and a $25 \mu \mathrm{m}$ nylon layer used for vacuum-packing in the meat industry was evaluated. The membrane was fixed on either side of a $30 \mathrm{~cm}$ long Perspex cylinder. The cylinder was completely filled with low oxygen content sea water and incubated in air-equilibrated sea water at $20^{\circ} \mathrm{C}$ and the oxygen content monitored. A $75 \mu \mathrm{m}$ polyethylene membrane was used in the tests for comparative reasons, as this material has been used in chamber studies by other authors (Hartwig 1976, Klump \& Marterns 1981, Anderson et al. 1986).

Chamber construction and general procedures. Four slightly different types of chambers were constructed. Firstly, chambers were constructed of transparent Perspex cylinders $(28.8 \mathrm{~cm}$ inside diameter and $6.1 \mathrm{~mm}$ wall-thickness) with a transparent $10 \mathrm{~mm}$ thick rigid Perspex top. Secondly, a transparent co-extruded membrane was fixed to similar cylinders to provide a flexible top. Thirdly, chambers were constructed of opaque $30 \mathrm{~cm}$ inside diameter PVC pipe with a $10 \mathrm{~mm}$ rigid Perspex top and lastly a similar PVC chamber was constructed with a co-extruded membrane top. In the latter 2 chambers black plastic linings eliminated light penetration. A diagram of a generalized chamber is presented in Fig. 2.

A $2.2 \mathrm{~cm}$ aperture on the side of each chamber enabled the water to escape from the chamber during careful placement by divers using SCUBA, minimizing bow-wave effects. After an equilibrium period of 20 min the aperture was sealed off with a rubber stopper. Samples were removed through a luer-lock plastic tap on the side of the chamber. A partial collapse of the chambers with membranes did compensate for the 
Table 2. A comparison of chambers used for in situ flux studies

\begin{tabular}{|c|c|c|c|c|c|c|c|c|c|c|}
\hline No & $\begin{array}{c}\text { Volume } \\
\text { (1! }\end{array}$ & $\begin{array}{l}\text { Area } \\
\left(\mathrm{cm}^{2}\right)\end{array}$ & $\begin{array}{l}\text { Flange } \\
\text { depth }\end{array}$ & Transparenc: & Mixing & Shape & Material & Measurements & Volume compensation & $\begin{array}{l}\text { Equilibrium } \\
\text { time (mini }\end{array}$ \\
\hline 1 & 60.0 & 1963 & 5 & Opaque & Stir (60 rpm) & Cylinder & Plexiglass & $-b^{b}$ & Polyethylene bag & - \\
\hline 2 & $4.7 / 18.0$ & $600-700$ & $13-30$ & Opaque/trans & - & - & - & Beginning/end & - & - \\
\hline 3 & 2094.0 & 31400 & 20 & Transparent & Stir & Hemisphere & Plexiglass & Continuous & - & - \\
\hline 4 & 4.2 & 209 & 3 & Opaque & - & Cylinder & Acrvlic & Beginning/end & - & 60 \\
\hline 5 & 38.0 & 3000 & - & Opaque & Pump $\left(10 \mathrm{~cm} \mathrm{~s}^{-1}\right)$ & Cylinder & Plexiglass & Periodic & - & 15 \\
\hline 6 & 32.0 & 1600 & 10 & - & Stir $\left(5-10 \mathrm{~cm} \mathrm{~s}^{-1}\right)$ & Square & Plexiglass & Periodic & None & 15 \\
\hline 7 & 10.0 & 774 & - & - & - & Cylinder & Stainless Steel & - & - & - \\
\hline 8 & 11.0 & - & - & Transparent & Stir $\left(2-20 \mathrm{~cm} \mathrm{~s}^{-1}\right)$ & Annulai & Plastic & Periodic/continuous & None & - \\
\hline 9 & $2.5-5.0$ & 412 & - & Opaque & Stir $(30-45 \mathrm{rpm})$ & Box & Stainless Steel & Periódic & Admitted outside water & $30-90$ \\
\hline 10 & 12.7 & 707 & 4 & $=$ & Stir & Cylinder & Plexiglass & Continuous & - & - \\
\hline 11 & 62.0 & 3100 & - & Transparent & Pump $\left(1-3 \mathrm{~cm} \mathrm{~s}^{-1}\right)$ & Cyinder & Plexiglass & Periodic/contiunous & Open tube to outside & - \\
\hline 12 & 18.0 & 700 & - & Opaque & Pump $\left\{300 \mathrm{ml} \mathrm{min}^{-1}\right)$ & - & Fibre-glass & Penodic & - & - \\
\hline 13 & 27.0 & 2400 & 4 & Opaque & Sér at sampling & Half cylinder & PVC & Beginning/end & None & - \\
\hline 14 & 24.4 & 1875 & - & Transparent & Pump & Turnel $(1.3 \mathrm{~m})$ & Plexiglass & Continuous (pump) & Flushing & - \\
\hline 15 & 7.9 & 707 & 6 & Opaque & Stir (25-30 rpm) & Cylinder & Aluminium & Periodic & Norie & $60-120$ \\
\hline 16 & 17.6 & 1452 & 6 & Opaque & Stir $(30 \mathrm{rpm})$ & Cylinder & Aluminium & Periodic & None: & $60-120$ \\
\hline 17 & 9.0 & 900 & 5 & - & None & Square & Plastic & - & Collapsible bag/plungers & - \\
\hline 18 & 6.1 & 700 & - & Transparent & Strir & - & Acrylic & Continuous & None & - \\
\hline$: 9$ & 3.5 & 443 & 4 & Opaque & Stur & Cylinder & Aluminium (coated) & End. & - & $8 \mathrm{~h}$ \\
\hline 20 & 32.0 & 2000 & 6 & Opaque & Stir & Hemisphere & Acrylic & Periodic/continuous & Adimitted outside water & - \\
\hline 21 & 47.5 & 2500 & 6 & Opaque & Stir & Hemispheré & Acryluc & Periodic & Admitted outside water & $15-30$ \\
\hline 22 & $30.0 \mathrm{~m}$ & - & - & - & None & Tunnel & Plastic sheet & - & None & - \\
\hline 23 & - & - & - & - & Pump $\left(1-4 \mathrm{~m}^{-1}\right)$ & Pointed rectangle & Epoxy-coated metal & Periodic & None & 15 \\
\hline 24 & 50.0 & 5030 & - & Opaque: & Stir & Cylinder & PVC & - & - & - \\
\hline 25 & 8.0 & 280 & - & Opaque & Stir & Cylinder & - & Periodic/continuous & Admitted outside water & - \\
\hline 26 & 294 & 3600 & 6 & Opaque & Pump $\left\{0.251 \mathrm{~s}^{-1}\right\}$ & Pyramid & Weided steel & Periodic & - & 15 \\
\hline 27 & 25.0 & 1960 & - & - & Pump & Cylinder & Acrilic & - & Admitted outside water & - \\
\hline 28 & 350 & 3850 & - & - & Pump & Cylinder & Acrylic & - & Adimitted ouiside water & - \\
\hline 29 & $0.9-1.6$ & $4: 2$ & - & Opaque & - & Box & Stainless Steel & Periodic & Admitted outside wates & $10-20$ \\
\hline 30 & 52.5 & 1590 & - & - & Stir & Cylinder & Plexiglass & Continuous & Opened at $2-4$ h interval & - \\
\hline 31 & 9.6 & 284 & - & - & Stir & Cylinder & Plexiglass & Continuous & Opened at $2-4$ h interval & - \\
\hline 32 & 4.0 & 400 & 10 & - & None & Tent & Plastic & Periodic & None & - \\
\hline 33 & 43.0 & 2376 & - & Opaque/trans & Stir/no stir & Hemsphere & - & Beginning/end & Opened during sampling & - \\
\hline 34 & 0.8 & 60 & - & Opaque/trans & Stir & - & Acrylic & Penodic & - & - \\
\hline 35 & $2-4$ & 570 & 5/none & Side/ti: lid/o & Stir & Cylinder & Plexiglass/PVC & Continuous & None & - \\
\hline 36 & 0.6 & 215 & 5 & Opaque/trans & Stir & Bottles & Glass & Beginning/end & - & - \\
\hline 37 & 7.3 & 731 & 10 & Opaque/trans & Stir at sampling & Cylinder & Perspex/PVC & Periodic & Admitted outside water & $20-30$ \\
\hline 38 & 0.5 & - & - & Transparent & Stir & Rerlangle & Perspes: & Continuous & Fushing & - \\
\hline 39 & 65 & 661 & - & - & Pump & Dome & Plexiglass & Periodic & - & - \\
\hline 40 & 05 & 45 & 20 & Opaque & - & Cylinder & PVC & Penodic & Admitted ouiside water & - \\
\hline 41 & 150 & 500 & Few $\mathrm{cm}$ & Transparent & - & Bottle & Class & Periodic (pump) & Replaced after sampling & - \\
\hline 42 & 20 & 500 & - & Opaque/trans & - & Bottle & Class & Penodic; begin/end' & - & - \\
\hline 43 & 1.0 & 64 & 6 & Opaque/trans & - & Cylinder & Plexiglass & Beginning/end? & - & - \\
\hline 44 & 75 & 730 & - & - & Stir & - & - & Beginning/end & - & - \\
\hline 45 & \pm 25.0 & 6600 & \pm 24 & Transparent & Stir & Cube & Plexiglass & Weekiy & Replaced through value & 1 wk \\
\hline 46 & 11.0 & 731 & - & Opaque & Stir & Cylinder & Plexiglass & Continuous & - & - \\
\hline 47 & 1.9 & 240 & 4 & Opaque/trans & Stir & Rectangle & Plexiglass & Periodic & None & 10 \\
\hline 48 & $1.9-7.5$ & 2995 & Seal edges & - & Stir at sampling & Cylinder & Plexiglass & - & None & - \\
\hline 49 & 98.2 & 1964 & 20 & Opaque & - & Cylinder & Stainless steel & Periodic & Balloons & - \\
\hline 50 & 2.5 & 651 & 10 & Trans/Opaque & Stir at sampling & Cylinder & Perspex & Periodic & Collapse of flexuble fop & 15 \\
\hline
\end{tabular}

volume of the sample removed (cf. Klump \& Martens 1981) and prevented high nutrient interstitial water flowing into the chamber In all cases the volume of sample removed (ca $10 \mathrm{ml}$ ) was $<0.5 \%$ of the total volume.
The chamber penetrated the sediment to $10 \mathrm{~cm}$ with ca $3.8 \mathrm{~cm}$ protruding above the surface. It had a volume of $2.5 \mathrm{l}$ and enclosed an area of $651 \mathrm{~cm}^{2}$. These values differed slightly for the dark chambers, but were taken into consideration during flux calculations 
Table 2 (continued)

\begin{tabular}{|c|c|c|c|c|c|c|}
\hline No. & $\begin{array}{l}\text { Exposure time } \\
\text { (h) }\end{array}$ & $\begin{array}{l}\mathrm{H}_{2} \mathrm{O} \text { column } \\
\text { correction }\end{array}$ & Fiux & Sämpling areà & Region & Soutce \\
\hline 1 & $60 \mathrm{~d}$ & - & $\mathrm{O}_{2}+$ nutrients & Fiord & Gullmarsfjorden, Western Sweden & Anderson et al. (1986) ${ }^{\mathrm{c}}$ \\
\hline 2 & $2-6$ & Yes & Nutrients & Nearshore & Königshaten, Wadden Seä, North Sea & Asmus (1982. 1986) \\
\hline 3 & $63 \mathrm{~d}$ & - & $\mathrm{O}_{2}+$ nutrients & Bight & Kiel Bight, Western Baltic & Balzer et al. (1983), Balzer (1984) \\
\hline t & 24 & - & $\mathrm{O}_{2}$ & Nearshore & Santa Barbara, California, USA & Baver et al. (1988) \\
\hline 5 & $1-3$ & Yes & $\mathrm{O}_{2}+$ nutrients & Estuary & Patuxent estuary, Chesapeake Bay, USA & Boynion et al. $(1980)^{d}$ \\
\hline 6 & 3 & Yes & Nutrients & Estuaty & Potomac river estury, Chesapeake Băy, USA & Callender (1982) \\
\hline 7 & - & - & $\mathrm{O}_{2}$ & 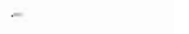 & North Sea + laboratory & Cramer (1989) \\
\hline 8 & 24 & - & $\mathrm{O}_{2}+$ nutrients & Open sea loch & Loch Thurnaig, Scotland & Davies (1975) \\
\hline 9 & $16-24$ & - & Nutrients & Oifishore & Skan Bay, Alaska and Mexico cont shelf & Devol (1987) \\
\hline 10 & - & - & $\mathrm{O}_{2}$ & Baltic, lakes, fivers & Baltic and lakes & Edberg \& Hoisten (1973) \\
\hline 11 & $2-4$ & - & $\mathrm{O}_{2}+$ nutrients & Estuaries & North Carolina, USA & Fisher et al. (1982) \\
\hline 12 & $\geq 3$ & - & $\mathrm{O}_{2}+\mathrm{NH}_{3}$ & Offshore & Northwestern Gulf of Mexico & Flint \& Kamykowski \{1984\} \\
\hline 13 & $2-4$ & Yes & $\mathrm{O}_{2}+$ nutrients & Estuary & Narragansett Bay, Rhode Island, USA & Hale $(1975)^{\circ}$ \\
\hline 14 & $1-10 d$ & Yes & $\mathrm{O}_{2}+\mathrm{P}$ & Tidal pond & Long Island, New' York, USA & Hall et a! (1979) \\
\hline 15 & 24 & Yes & $\mathrm{O}_{2}+\mathrm{CO}_{2}+\mathrm{P}$ & - & - & Hargrave \& Connolly $(1978)^{9}$ \\
\hline 16 & 24 & Yes & $\mathrm{O}_{2}+\mathrm{CO}_{2}$ & Estuaty & Eastern passage, Halifay Harb., NS, Canada & Hargrave \& Phillyps (1981) \\
\hline 17 & $\leq 6$ & Yes & Nutrients & Nearshore & La Jolla Bight USA & Hartwig (1976) \\
\hline 18 & 24 & Yes & $\mathrm{O}_{2}$ & Nearshore & Gulf of Trieste, Northern Adriatic Sea & Herndl et al. (1989) \\
\hline 19 & - & - & $\mathrm{O}_{2}+$ nutrients & Olfshore & North Allantic deep-sea & Hinga et al. (1979) \\
\hline 20 & 4 & Yes & $\mathrm{O}_{2}+$ nutrients & Nearshore & Georgiä Bight, USA & Hopkinson \& Wetzel (1982) \\
\hline 21 & 4 & Yes & Nutrients and $\mathrm{O}_{2}$ & Nearshore & Georgia Bight, USA & Hopkinson $\mid(1987)^{k}$ \\
\hline 22 & - & - & $\mathrm{O}_{2}$ & Streams & England, various sites & James (1974) \\
\hline 23 & - & - & $\mathrm{O}_{2}$ & Streams and lakes & England, various sites & James (1974) \\
\hline 24 & - & - & $\mathrm{O}_{2}$ & Nedrhore & Seto inland sea, Japan & Kawana et al. (1987) \\
\hline 25 & $10 \mathrm{~d}$ & Yes & $\mathrm{O}_{2}+$ nutrients & Lake & Lake Grevelingen, Netherlands & Kelderman ef al. (1988) \\
\hline 26 & $1-3$ & Yes & $\mathrm{O}_{2}$ & Estuary & Chesapeake Bay, USA & Kemp \& Boynton (1981) \\
\hline 27 & - & Yes & $\mathrm{NH}_{3}+\mathrm{P}$ & Nearshore & Cape Lookout Bight, N Carolina, USA & Klump \& Martens (1981) \\
\hline 28 & - & Yes & $\mathrm{NH}_{3}+\mathrm{P}$ & Nearshore & Cape Lookout Bight, N Carolinä, USA & Klump \& Martens (1981) \\
\hline 29 & 15 & - & $\mathrm{O}_{2}+$ methane & Lake & Lake Washington. Seattle, USA & Kuivila ef al. (1988) \\
\hline 30 & 48 & Yes & $\mathrm{O}_{2}$ & Nearshore & Flores Sed, Indonesia & Lindeboom \& Sandee $(1989)$ \\
\hline 31 & 48 & Yes & $\mathrm{O}_{2}$ & Nearshore & Flores Sea, Indonesia & Lindeboom \& Sandee [1989] \\
\hline 32 & $1-2$ & - & Methane & Nearshore & Cape Lookout Bight, N Carolina, USA & Martens \& Klump (1980) \\
\hline 33 & $3-4$ & Yes & $\mathrm{O}_{2}+$ rutrients & Lagoon & Colorado lagoon, Long Beach, Calif. USA & Murphy \& Kremer $\{1985\}$ \\
\hline 34 & 4 & Yes & $\mathrm{O}_{2}+$ nutrients & - & Chesapeake Bay, USA & Murray \& Wetze] [1997) \\
\hline 35 & $2->6$ & - & $\mathrm{O}_{2}$ & Nearfoff shore & Puget Sound, Washington, USA & Pamatmat \& Fenton (1968) \\
\hline 36 & $0.5-1.5$ & Yes & $\mathrm{O}_{2}$ & Intertidal sandflat & False Bay, Sari Juan is, Washington, USA & Pamatmat (1968) \\
\hline 37 & $2-22$ & - & - & - & - & Patching \& Raine (1983) \\
\hline 38 & $24-36$ & - & $\mathrm{O}_{2}$ & - & Canibbean & Pearson et al (1984) \\
\hline 39 & $2-4$ & Yes & $\mathrm{O}_{2}$ & Infralittoral & Aqaba Gulf: Red Sea & Peres (1982) \\
\hline 40 & $4-6.5$ & Yes & Nutrients & Nearshore & Nahant Bay, Massachusetts, USA & Pregnall \& Miller (1988) \\
\hline 41 & $9-10$ & Yes & $\mathrm{O}_{2}+$ nutrients & Nearshore & Vostok Bay, Sea or Japan & Propp et al $\{1980\}$ \\
\hline 42 & $5-26$ & Yes & $\mathrm{O}_{2}+$ riutrients & Bay & Vostok Bay, Sea of Jüpan & Propp (1977) \\
\hline 43 & $1-3$ & Yes & $\mathrm{O}_{2}$ & Estuary & York River, Chesapeake Bay, USA & Rizzo \& Wetzel (1985) \\
\hline 44 & - & - & $\mathrm{O}_{2}+$ nutrients & - & Cap Blanc, Spanish Sahara & Rowe et al. (1977) \\
\hline 45 & Months & - & $\mathrm{O}_{2}, \mathrm{pH}, \mathrm{Eh}, \mathrm{E}_{5}$ & - & - & Schippel et al. (1973) \\
\hline 46 & 4 & - & $\mathrm{O}_{2}$ & Nearshore & Castle Harbor, Bermuda & Smith et al. (1972) \\
\hline 47 & 6 & Yes & DIC & Lake & Canadian lake & Sweerts et al. (1986) \\
\hline 48 & 24 & - & $\mathrm{O}_{2}$ & Lake & Char Lake, N Canada & Welch \& Kalff $\{1974\}$ \\
\hline 49 & - & Yes & Nutnents & Nearshore & Hiuchı Nada, Suho Nada and Beppu Bay, Japan & Yamada \& Kayama (1987) \\
\hline 50 & 3 & Yes & $\mathrm{O}_{2}$ & Nearshore & Algoa Bay, South Africa & This study \\
\hline \multicolumn{5}{|c|}{$\begin{array}{l}\text { 'Also used by Rutgers van der Loeff et al. (1984), Sundby et al. (1986), Hall (1984), } \\
\text { Hall et al. (1989) and Westerlund et a). (1986) }\end{array}$} & \multicolumn{2}{|c|}{ 'Also used by McCaffrey et al. (1980), Nixon ell al. $(1976,1980)$ and Elderfield et al. (1981) } \\
\hline \multicolumn{5}{|c|}{${ }^{d}$ Also used by Callender \& Hammond (1982) and Boynton et al. (1981) } & \multicolumn{2}{|c|}{$\begin{array}{l}\text { Also used by Kelzer et a) (1989) (but volume ca } 17 \text {.) and Hargrave \& Phillips (1986) } \\
\text { "Also used by Fallon et al. (1983) and Hopkinson (1985) }\end{array}$} \\
\hline \multicolumn{5}{|c|}{ ¿Also used by Callender \& Hammond (1982) } & \multicolumn{2}{|l|}{ ' Also used by Pamatmat \& Banse $(1969)$} \\
\hline
\end{tabular}

This small volume to area ratio increased exchanges during shorter incubation periods and inhibited the build-up of concentration gradients. This, and the wave action at these shallow stations, eliminated the need for stirring. Stirring was also omitted because the aim of this study was to examine the effect of wave action and different stirring speeds can drastically influence flux rates (Dye 1979, Boynton et al. 1981, Callender \& Hammond 1982, Olah et al. 1987) with even more pronounced effects when sediment resus- 


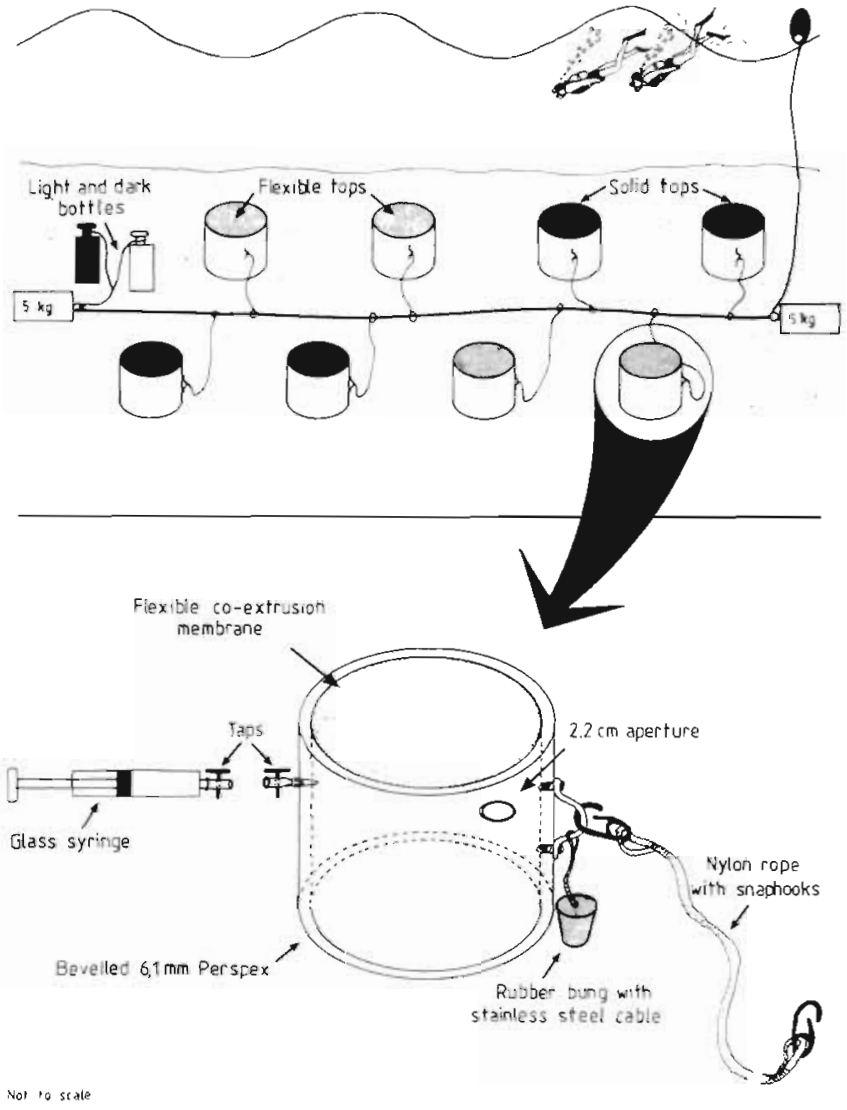

Fig. 2. Schematic representation of setup during chamber employments, with detailed inset of a chamber

pension occurs (Edwards \& Rolley 1965, Pamatmat 1977. Boynton et al. 1981)

Oxygen flux determinations, at $18 \pm 2^{\circ} \mathrm{C}$, were performed at $0.5 \mathrm{~m}$ and $5 \mathrm{~m}$ depth below low-water spring tide (ca $20 \mathrm{~m}$ and $150 \mathrm{~m}$ offshore), representing respectively the inner and outer turbulent zones of this beach (McLachlan et al. 1984) In situ oxygen flux determinations were usually conducted simultaneously with 6 to 8 chambers. The side-wash and visibility, however, influenced the number of chambers that could be successfully employed.

The general procedure followed is clear from Fig. 2. After an equilibration time of 20 min oxygen samples were taken at 30 to $45 \mathrm{~min}$ intervals during the total incubation time of 2 to $4 \mathrm{~h}$. Samples were taken with acid-cleaned glass syringes equipped with plastic stopcocks, after gently mixing the contents of the chamber with a $50 \mathrm{ml}$ syringe. Dye studies showed this method of mixing to be adequate. The syringes were stored at between -2 and $+2{ }^{\circ} \mathrm{C}$ without freezing and immediately analyzed on arrival at the laboratory. Oxygen flux was calculated using chamber volume, area, incubation time and results of light and dark bottles for correction of uptake in overlying water.
Statistics. In general the data was checked for normality and homoscedasticity. This was normally followed by a 1-way analysis of variance and a multiple range test. In certain cases the independent variable had to be transformed $\left[X_{1}=(X+0.5)^{0.5}\right]$ to yield a straight line before the slopes were compared. Intercepts were not compared as the experimental design sometimes resulted in differing initial oxygen concentrations.

\section{RESULTS}

\section{Oxygen permeability of different materials}

The permeability of plastic and glass syringes to oxygen diffusion differed significantly $(p<0.001)$. Both makes of plastic syringes were highly permeable to oxygen, even at small gradients (Fig. 3). The different makes of plastic syringes also varied in oxygen permeability. The all-glass syringes were virtually impermeable to oxygen. The slight increase in oxygen observed in the latter is probably the consequence of oxygen penetrating through the plastic stopcocks.

Storage time had little effect on oxygen concentrations of water samples in glass syringes (Fig. 4). In this experiment, conducted at $20^{\circ} \mathrm{C}$ (compare actual transport conditions of $<2{ }^{\circ} \mathrm{C}$ ), there was a slight oxygen reduction in the unfiltered sea water samples. This effect might be increased, or decreased, during days of varying activity in the water column. Under the conditions tested, glass syringes may be used to collect and store oxygen samples for periods up to $12 \mathrm{~h}$, without inducing errors.

The oxygen permeability of the materials investigated for volume compensation differed significantly $(p<0.001)$ (Fig. 5). Whilst the experimental oxygen gradients were far steeper than would be expected under field conditions, clearly condoms (Latex rubber) and polyethylene are not suitable materials. The coextrusion was significantly less permeable to oxygen, but still showed some leakage. The success of this coextrusion used for the flexible membrane chamber lies in the fact that the nylon layer retards oxygen diffusion, while the polyethylene layer supplies strength. According to Brydson (1975). Nylon 6 is 145 times less permeable to oxygen than low density polyethylene

Oxygen penetration through the 2 materials initially considered for the flexible membrane, polyethylene and the co-extrusion, differed significantly $(p<0.001)$ (Fig. 6). The co-extrusion membrane should also perform better under field conditions where the oxygen gradients would be considerably reduced. Opaque chambers left in the sediment for extended periods resulted in complete oxygen removal. This indicated that signifi- 


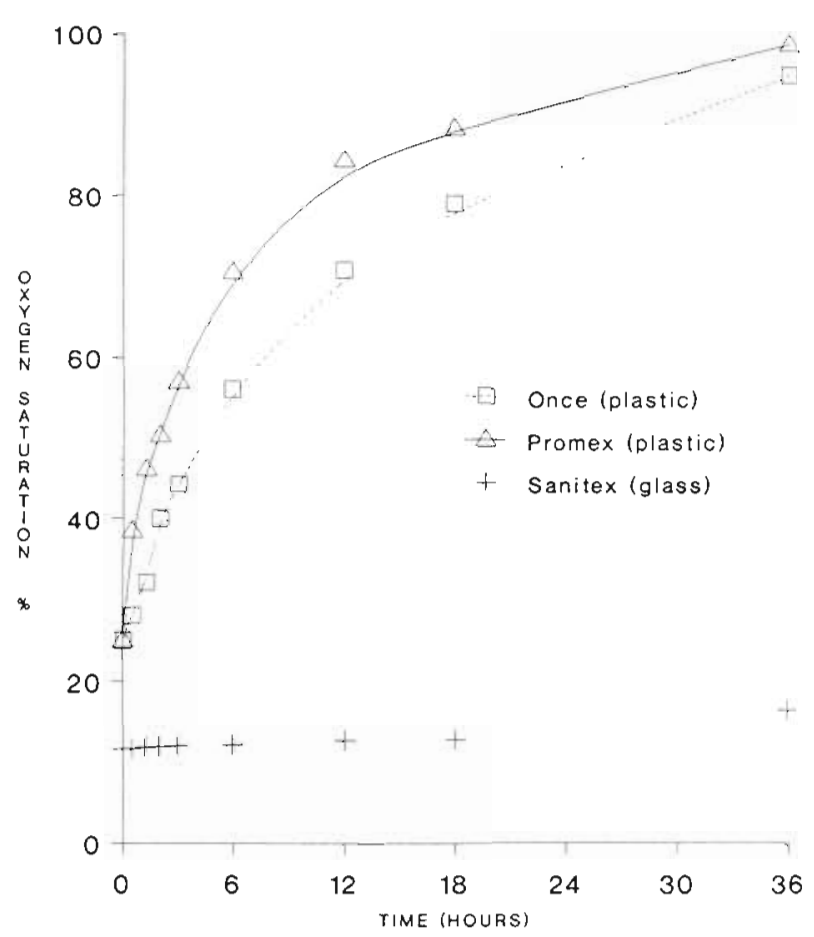

Fig. 3. Oxygen permeability of plastic and glass syringes

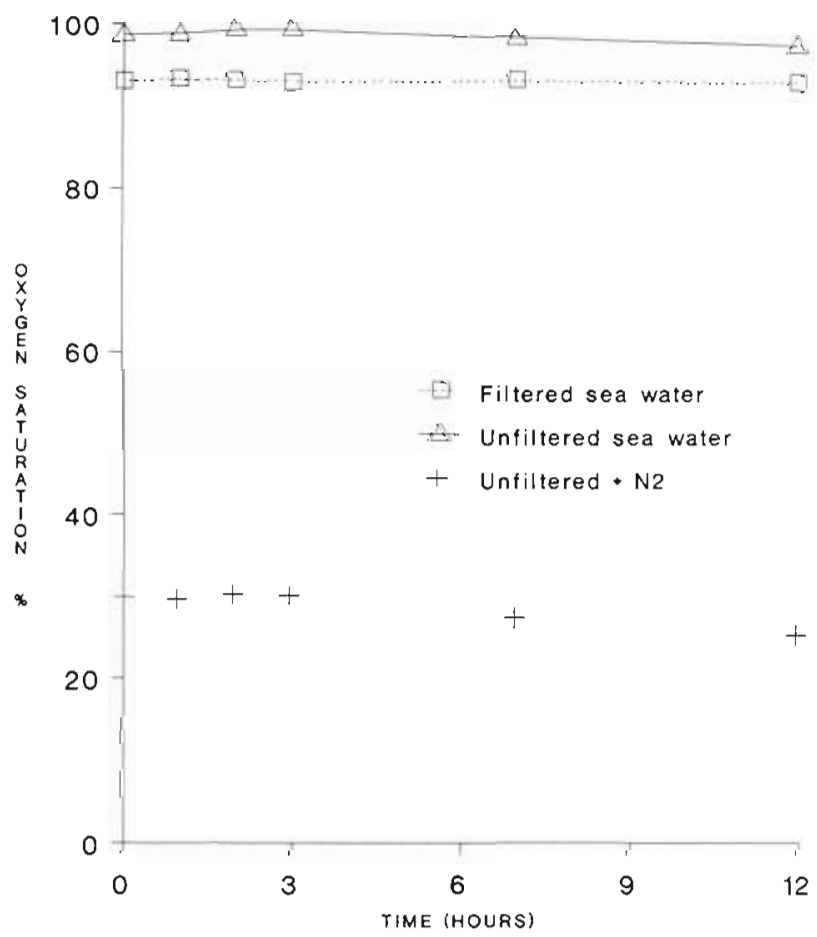

Fig. 4. Effect of time delay before oxygen analysis of water samples transported at $20^{\circ} \mathrm{C}$ in glass syringes

cant amounts of oxygen did not penetrate through the membrane, or that depletion was faster than leaking. In contrast, oxygen concentrations in chambers with polyethylene tops were never reduced to zero.

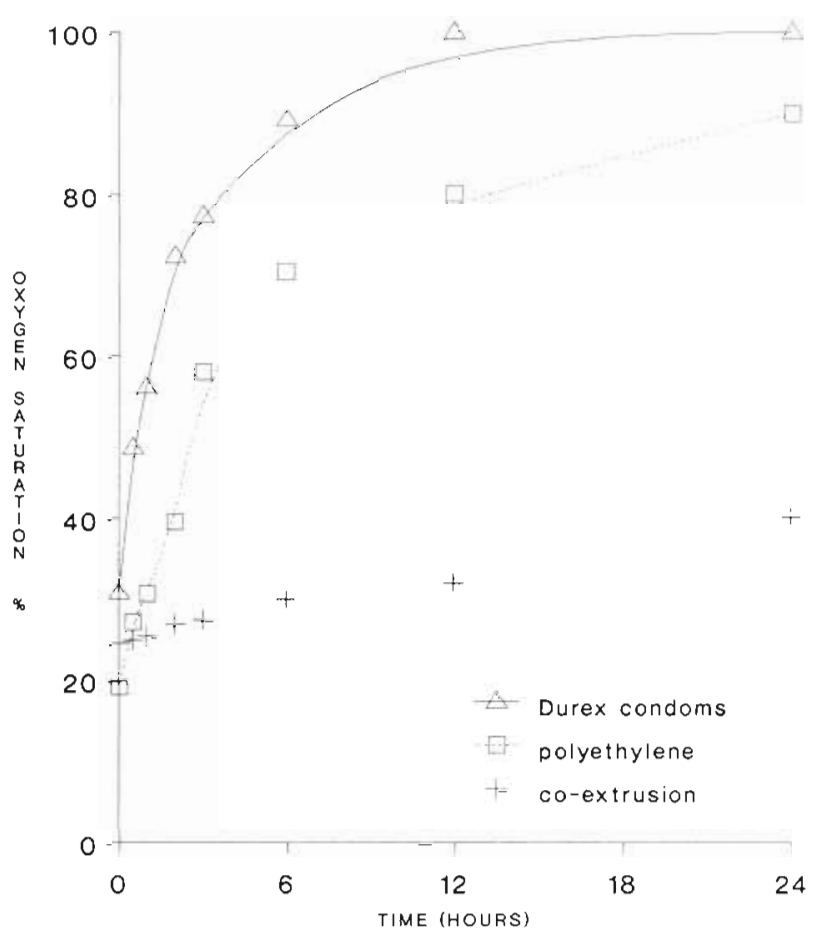

Fig. 5. Oxygen permeability of different materials investigated for volume compensation purposes

\section{Oxygen consumption}

ANOVA and multiple range analysis (Zar 1974) of the oxygen flux data revealed that there was no statistically significant difference $(p>0.05)$ between the 2 stations. Light and dark chambers with flexible tops showed no statistically significant difference (ANOVA and multiple range analysis, $p=0.20$ ). Similarly the light and dark chambers with solid tops were homogeneous $(\mathrm{p}=0.97)$. Data from all flexible top chambers and all solid top chambers were therefore pooled. ANOVA and multiple range analysis showed that the oxygen depletion in the flexible chambers was significantly different from the solid chambers $(p<0.005)$. The oxygen fluxes in the flexible and solid top chambers were respectively $18.5 \pm 2.7(95 \% \mathrm{CI})$ and $10.7 \pm 4.6 \mathrm{ml} \mathrm{O}_{2} \mathrm{~m}^{-2} \mathrm{~h}^{-1}$ (average of 123 chamber values).

Using the results of the flexible membrane chambers at the Kings Beach $4 \mathrm{~m}$ station, a comparison was made between oxygen consumption during very calm $(<0.25 \mathrm{~m})$ and average $(1 \mathrm{~m})$ wave conditions. Despite a small sample size for the calm condition $\left(n_{1}=20\right.$; $\mathrm{n}_{2}=97$ ), there was a significant (ANOVA, $\mathrm{p}<0.05$ ) difference between these 2 physical conditions. Oxygen consumption during the very calm sampling periods averaged $9.4 \pm 6.1 \mathrm{ml} \mathrm{O}_{2} \mathrm{~m}^{-2} \mathrm{~h}^{-1}$ compared to $16.0 \pm 2.8 \mathrm{ml} \mathrm{O}_{2} \mathrm{~m}^{-2} \mathrm{~h}^{-1}$ during slightly rougher conditions. 


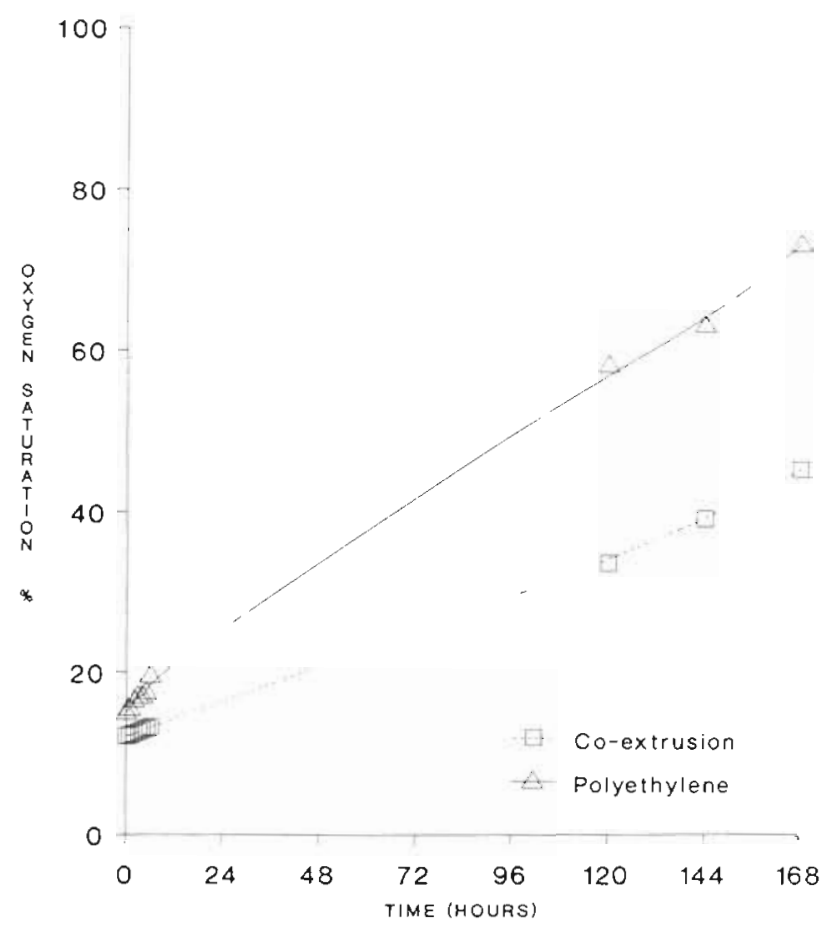

Fig. 6. Oxygen permeability of different materials investigated for the flexible membrane of the chamber

\section{DISCUSSION}

Kings Beach sediments are porous (Table 1) with oxygen penetrating to depths exceeding $60 \mathrm{~cm}$ (Malan \& McLachlan 1985). There must therefore be considerable water exchange between the interstitial system and the overlying water. Measurement of the oxygen consumption of this benthic system therefore needs to include the pumping effect of the waves.

The many different methods used to investigate benthic metabolism have been reviewed by several authors (Bowman \& Delfino 1980, Patching \& Raine 1983). Despite this, there is still wide-spread disagreement about the best method to determine oxygen consumption. We felt that under our environmental conditions a fairly large in situ chamber with a flexible top would yield the best results, because such a chamber would: (1) most closely mimic the natural changes in hydrostatic pressure caused by surface waves passing overhead, (2) reduce the spatial variability of bottom fauna, (3) preclude unnaturally high consumption figures caused by handling, (4) preserve interstitial profiles, (5) emulate natural light and temperature regimes and (6) avoid decompression problems.

Materials and equipment used for the construction of chambers or used during sampling and analysis must be impermeable to oxygen. The permeability of different materials to oxygen varies tremendously (Brydson 1975). Plastic (Welch \& Kalff 1974, Hargrave
\& Connolly 1978) and PVC syringes (Flint \& Kamykowski 1984) have previously been used during experiments for determination of the oxygen content in water samples. Welch \& Kalff (1974) found considerable variation in oxygen consumption values and attributed this to the blood-gas analyzer used. This variability could have been due to oxygen diffusion through their plastic syringes. Hargrave \& Connolly (1978) mentioned that their plastic syringes were permeable to oxygen, but did not apply any correction for this. Martens \& Klump (1980) estimated that the loss of methane through their plastic syringes was $<11 \%$. Pamatmat \& Banse (1969) and Pamatmat (1971) considered their oxygen consumption rates underestimates, since the $1.6 \mathrm{~mm}$ thick Tenite core liners used were permeable to dissolved oxygen. Laane et al. (1985) conducted laboratory studies to determine oxygen consumption resulting from photooxidizing processes. Oxygen concentrations were monitored in 'blood transfusion bags'. These authors, however, did not mention if these bags were impermeable to oxygen. Glass syringes have been used by many people for collecting oxygen samples (Hargrave 1972, Anderson et al. 1986, Sundby et al. 1986, Bender et al. 1989), and proved to be very effective in this study (Fig. 4), even at steep oxygen concentration gradients (Fig. 3).

The evidence presented here on the leakage of oxygen through plastic syringes and many of the materials previously used in chamber construction shows that there have been serious shortcomings in some authors' equipment. Although many authors have compensated for the permeability of their equipment, for example plastic syringes (McLachlan 1977, Martens \& Klump 1980), others have ignored it or appear to have been unaware of the problem. Although the initial oxygen gradients in the current experiments were large, considerable leakage occurred even at gradients that would normally be expected under field conditions (Figs. $3 \& 5$ ). It is thus clear that some of the oxygen consumption, production, carbon budgets etc. previously reported on in the literature could be suspect. This aspect becomes even more serious if one considers the large variabilities and small sample sizes, often less than 5 to 10 measurements, that many authors report on (Malan \& McLachlan unpubl.).

If the data represented in Table 2 is a fair reflection of the wide range of chambers used during in situ chamber deployments, several interesting facts emerge. Less than $30 \%$ of the chambers have volumes smaller than 51 , whilst $50 \%$ are smaller than 101 . The other $50 \%$ range between 10 and $>60 \mathrm{l}$. The average volume (excluding the largest chamber of over 2000 I) of the chambers presented here is $19 \pm 21 \mathrm{l}$. Only a small percentage $(25 \%)$ of the chambers cover a sedi- 
ment surface of $\leq 500 \mathrm{~cm}^{2}$, with the majority falling in the range 500 to $2000 \mathrm{~cm}^{2}$. It is further noticeable that the chambers often do not penetrate deep into the sediment. While this might be suitable under low energy and anaerobic sediment conditions, it might present problems under high energy conditions with considerable interstitial water flow. Although it was sometimes possible to keep chambers in place for more than a day, only the first few hours of the data could be used. After this period the sediment surrounding the chambers was scoured away causing a leakage of oxygen and hence unreliable results.

Plexiglass is the most popular construction material for chambers and the preferred shape is cylindrical. Although some authors used both transparent and opaque chambers, most make use of opaque materials. Roughly half of the studies in Table 2 made allowance for compensation of water column activity, with even fewer making allowance for the effect of sample removal. Whereas some authors recorded variables continuously, the majority took periodic readings or only initial and final values. Roughly $60 \%$ of the investigators used some method to mix the volume of water enclosed inside their chambers. These methods range from pumps and paddles to magnetic stirrers, all with different flow and stirring speeds, making it very difficult to compare data. Some researchers only stirred the water to prevent the formation of concentration gradients, while others attempted to mimic natural conditions. For example, Murphy \& Kremer (1985) matched mixing rates both within and outside their chamber, by comparing the erosion weight loss from $\mathrm{CaSO}_{4}$ chips. Although this will not compensate for the effect of the sub-tidal pump, it is an improvement on the normal procedures. Buchholtz-ten Brink et al. (1989) went to great lengths to calibrate the performance of their stirred benthic chamber.

Few authors allowed any equilibrium time before measurements commenced. The importance of this has clearly been shown before, especially if the sediment surface is covered in a fine flocculent material. It can only be assumed that most authors do in fact allow for this, but neglect to mention it in their papers. Examination of the different exposure times suggests 3 groupings. Firstly, short-term exposures in the range 1 to $4 \mathrm{~h}$, secondly exposures of about $24 \mathrm{~h}$ and thirdly exposure of 10 and more days are found. The physical conditions and depth of the sampling site play an important role in determining exposure time. Shallow areas are frequently affected by tidal currents, wave climate and scouring with intermediate depths restricting bottom time of SCUBA divers. Deeper sampling stations require specialized and costly equipment such as freevehicle respirometers and submersibles (Smith \& Teal 1973, Smith 1974, Smith \& Baldwin 1984).
From the above and Table 2 it is clear that a large variety of different chambers, construction materials and methods, stirring speeds, depth of penetration and equilibrium times are being used. Many authors further fail to adequately report on their materials and methods. This makes comparison with other data extremely difficult. It is unlikely that anybody will one day develop the ideal chamber that is inexpensive, simple to construct, will operate under all conditions, mimic environmental conditions exactly and will be accepted by all researchers. It is, however, urged that authors do at least report as much detail as possible regarding their equipment, sampling procedures and environmental conditions as this will help in the interpretation of their data and make comparisons easier and more reliable.

The preliminary data presented here on oxygen consumption indicated that values are in the same range as reported by other authors for nearshore sandy sediments (Smith et al. 1972, Rowe et al. 1977, Propp et al. 1980). The data further showed that flux in the flexible chambers was $73 \%$ higher than flux in the solid top chambers. We propose that the differences in the respective fluxes can be entirely attributed to the effect of wave action. To test this hypothesis the station with the most data was used to compare 2 different wave regimes. Although the difference in wave height was only $0.75 \mathrm{~m}$, this represented a 4 -fold increase in wave height at this shallow station. This resulted in a $70 \%$ increase in oxygen consumption during the more exposed conditions. We feel that the large difference found between flexible and solid top chambers, together with the similarly large difference found under different wave regimes, indicates that wave action influences oxygen consumption at our study site.

A large majority of workers have not tried to measure respiration in shallow high energy environments. Sampling sites are often in deeper and/or calmer areas and these authors have not previously had to deal with the effect of wave action. It should also be pointed out that sediment characteristics and water depth of many of the study sites recorded in Table 2 are probably of such a nature that interstitial water flow is possibly not a very important factor. Nevertheless, the effect of interstitial water flow resulting from hydrostatic pressure fluctuations caused by passing surface waves can clearly not be ignored in shallow areas. Although Asmus (1982) equipped his bell jars with a polyethylene-polyamide plastic film to transfer wave action to the contents of the jars, to the best of our knowledge no authors have previously experimentally determined the effect of the 'sub-tidal pump' on oxygen consumption. We infer that, depending on such factors as wave action, water depth, sediment porosity and permeability, authors working in shallow areas could have under- 
estimated oxygen flux rates by as much as $50 \%$. It is our opinion that this effect caused by the pumping effect of the waves could potentially play an important rôle in all benthic systems where the sampling depth is less than half the wave length. In the nearshore coastal region it is expected to correspond roughly with the outer limit of the dynamic swept prism at a depth of about 15 m (Chapman 1983, Swart 1983). Beyond this depth the importance of the sub-tidal pump will rapidly diminish, although Riedl et al. (1972) mentioned that it could be effective to the $200 \mathrm{~m}$ isobath.

The oxygen fluxes presented here for the Kings Beach study site should be considered conservative estimates, since sampling only took place under relatively calm conditions. Further, although the effects of wave action were included by using flexible membrane tops on the chambers, the effect of the bottom surge (which is normally present at these shallow stations) was excluded by the solid vertical walls of the chamber

In conclusion it can be said that the chamber introduced is inexpensive, easy to construct and appears to adequately allow for the interstitial pumping effect of waves in this shallow marine area studied. It has further been shown that waves have a pronounced effect on oxygen consumption in this shallow high energy coast. Evidence presented demonstrated that many of the materials and equipment previously used are highly permeable to oxygen and unsuitable for oxygen-related studies.

Acknowledgements. We thank our colleagues and the students who assisted with the diving work, especially Dr A. C. Cockcroft, Mr D. van der Merwe and Mr B. Tomalin. The constructive comments on an earlier version of the manuscript by Prof. A. Dye and 2 anonymous referees are appreclated. The Kohler Flexible Packaging firm is gratefully acknowledged for supplying the co-extrusion material. This study was partly funded by the South African National Committee for Oceanographic Research and the Cape Department of Nature and Environmental Conservation.

\section{LITERATURE CITED}

Alongi, D. M., Boto, K. G., Tirendi, F. (1989). Effect of exported mangrove litter on bacterial productivity and dissolved organic carbon fluxes in adjacent tropical nearshore sediments. Mar Ecol. Prog. Ser 56: 133-144

Anderson, L. G., Hall, P. O. J., Iverfeldt, A., Rutgers van der Loeff, M. M., Sundby, B., Westerlund, S. F. G. (1986) Benthic respiration measured by total carbonate production. Limnol. Oceanogr. 31. 319-329

Asmus, R. (1982). Field measurements on seasonal variation of the activity of primary producers on a sandy tudal flat in the Northern Wadden Sea. Neth. J. Sea Res. 16: 389-402

Asmus, R. (1986). Nutrient flux in short-term enclosures of intertidal sand communities. Ophelia 26: 1-18

Balzer, W. (1984). Organic matter degradation and biogenic element cycling in a nearshore sediment (Kiel Bight). Limnol. Oceanogr 29: 1231-1246

Balzer, W., Grasshoff, K., Dieckmann, P., Haardt, H., Petersohn, U. (1983). Redox-turnover at the sediment/water interface studied in a large bell jar system. Oceanol. Acta 6: 337-344

Bauer, J. E., Montagna, P. A., Spies, R. B., Prieto, M. C., Hardin, D. (1988). Microbial biogeochemistry and heterotrophy in sediments of a marine hydrocarbon seep. Limnol. Oceanogr. 33: 1493-1513

Bay, D. (1982). Biologie marine - Etude in situ du metabolisme de trois communautes benthiques infralittorales du Golfe d'Aqaba-Mer Rouge. C.R. Acad. Sci., Paris 294: 463-466

Beckley, L. E. (1988). Spatial and temporal variability in sea temperature in Algoa Bay, South Africa. S. Afr Tydskr. vir Wetenskap 84:67-69

Bender, M., Jahnke, R., Weiss, R., Martin, W., Heggie, D. T., Orchardo, J., Sowers, T (1989). Organic carbon oxidation and benthic nitrogen and silica dynamics in San Clemente Basin, a continental borderland site. Geochim. Cosmochim. Acta 53: 685-697

Bowman, G. T., Delfino, J. J. (1980). Sediment oxygen demand techniques: a review and comparison of laboratory and in situ systems. Wat. Res. 14: 491-499

Boynton, W R., Kemp, W. M., Osborne, C. G. (1980). Nutrient fluxes across the sediment-water interface in the turbid zone of a coastal plain estuary. In: Kennedy, V. S. (ed.) Estuarine perspectives. Academic Press, New York, p. 93-109

Boynton, W R., Kemp, W. M., Osborne, C. G., Kaumeyer, K. R., Jenkins, M. C. (1981). Influence of water circulation rate on in situ measurements of benthic community respi. ration. Mar Biol. 65: 185-190

Brydson, J. A. (1975). Plastic materials. Whitefriars Press Ltd, London

Buchholtz-ten Brink, M. R., Gust, G., Chavis, D. (1989). Calibration and performance of a stirred benthic chamber. Deep Sea Res. 36: 1083-1101

Callender, E. (1982). Benthic phosphorus regeneration in the Potomac river estuary. Hydrobiol. 92: 431-446

Callender, E., Hammond, D. E. (1982). Nutrient exchange across the sediment water interface in the Potomac River Estuary. Estuar coast. Shelf Sci. 15: 395-413

Carey, A. G. Jr (1967). Energetics of the benthos of Long Island Sound 1 Oxygen utilization of sediment. Bull. Bingham Oceanogr. Coll. 19: 136-144

Carstens, I (1968). Wave forces on boundaries and submerged bodies. Sarsia 34:37-60

Chapman, D. M. (1983). Sediment reworking on sandy beaches. In. McLachlan, A, Erasmus, $T$ (eds.) Sandy beaches as ecosystems. Junk. The Hague, p. 45-62

Cramer, A. (1989). A common artefact in estimates of benthic community respiration caused by the use of stainless steel. Neth. J. Sea Res. 23: 1-6

Davies, J. M. (1975). Energy flow through the benthos in a Scottush Sea loch. Mar. Biol. 31: 353-362

Devol, A. H. (1987). Verification of flux measurements made with in situ benthic chambers. Deep Sea Res. 34: $1007-1026$

Dye, A. H. (1979). Measurement of biological oxygen demand in sandy beaches. S. Afr Tydskr. Dierk. 14:55-60

Dyrssen, D. (1986). Chemical processes in benthic flux chambers and anoxic basin waters. Neth. J. Sea Res. 20 $225-228$

Dyrssen, D., Hall, P., Westerlund, S. (1984). Benthic chamber chemistry. Symposium on inorganic analysis in environmental research and protection, Juelich (FRG), 13-16 June 1983. Fresenius Z. Anal. Chem. 317: 380-382 
Edberg, N., Hofsten, B. V (1973). Oxygen uptake of bottom sediments studied in situ and in the laboratory. Wat. Res. 7: $1285-1294$

Edwards, R. W., Rolley, H. L. J. (1965). Oxygen consumption of river mud. J. Ecol. 53 1-19

Elderfield, H., Luedtke, N., McCaffrey, R. J., Bender, M. (1981). Benthic flux studies in Narragansett Bay. Am. J. Sci. $281 \quad 768-787$

Fallon, R. D., Newell, S. Y., Hopkinson, C. S. (1983). Bacterial production in marine sediments: will cell-specific measures agree with whole-system metabolism? Mar. Ecol. Prog. Ser. 11: 119-127

Fisher, T R., Carlson, P. R., Barber, R. T. (1982). Sediment nutrient regeneration in three North Carolina estuaries. Estuar. coast. Shelf Sci. 14: 101-116

Flint, R. W., Kamykowski, D. (1984). Benthic nutrient regeneration in South Texas coastal waters. Estuar. coast. Shelf Sci. $18 ; 221-230$

Gust, G. (1977). Turbulence and waves inside flexible-wall systems designed for biological studies. Mar Biol. 42: $47-53$

Hale, S. S. (1975). The role of benthic communities in the nitrogen and phosphorous cycles of an estuary. In: Howell, F. G., Gentry, F. G., Smith, M. H. (eds.) Proceedings of a symposium on mineral cycling in Southeaster ecosystems. Publ. Tech. Information Centre: U.S. Energy and Development Admin., Augusta, Georgia, p. 291-308

Hall, C. A. S., Tempel, N., Peterson, B. J. (1979). A benthic chamber for intensely metabolic lotic systems. Estuaries 2: 178-183

Hall, P. (1984). Chemical fluxes at the sediment-seawater interface; in situ investigations with benthic chambers. Ph. D. thesis, Chalmers University of Technology and University of Goteborg

Hall, P. O. J., Anderson, L. G., Rutgers van der Loeff, M. M., Sundby, B., Westerlund, S. F. G. (1989). Oxygen uptake kinetics in the benthic boundary layer. Limnol. Oceanogr 34: 734-746

Hallberg, R. O., Bågander, L. E., Enguall, A.-G., Schippel, F. A. (1972). Method for studying geochemistry of sediment-water interface. Ambio 1: 71-72

Hargrave, B. T. (1972). Oxidation-reduction potentials, oxygen concentration and oxygen uptake of profundal sediments in a eutrophic lake. Oikos 23: 167-177

Hargrave, B. T., Connolly, G. F. (1978). A device to collect supernatant water for measurement of the flux of dissolved compounds across sediment surfaces. Limnol. Oceanogr 23: 1005-1010

Hargrave, B. T., Phillips, G. A. (1981). Annual in situ carbon dioxide and oxygen flux across a subtidal marine sediment. Estuar. coast. Shelf Sci. 12: 725-737

Hargrave, B. T., Phillips, G. A. (1986). Dynamics of the benthic food web in St. Georges Bay, southern Gulf of St. Lawrence. Mar. Ecol. Prog. Ser. 31: 277-294

Hartwig, E. O. (1976). The impact of nitrogen and phosphorus release from a siliceous sediment on the overlying water In: Wiley, M. (ed.) Estuarine processes, Vol. 1. Uses, stresses, and adaptations to the estuary. Academic Press, New York, p. 103-117

Herndl, G. J., Peduzzi, P., Fanuko, N. (1989). Benthic community metabolism and microbial dynamics in the Gulf of Trieste (Northern Adriatic Sea). Mar. Ecol. Prog. Ser. 53: $169-178$

Hinga, K. R., Sieburth, J. M., Heath, G. R. (1979). The supply and use of organic material at the deep-sea floor $\mathrm{J}$. mar. Res. 37: $557-579$

Hopkinson, C. S. Jr (1985). Shallow-water benthic and pelagic metabolism: evidence of heterotrophy in the nearshore Georgia Bight. Mar. Biol. 87: 19-32

Hopkinson, C. S. Jr (1987). Nutrient regeneration in shallowwater sediments of the estuarine plume region of the nearshore Georgia Bight, USA. Mar. Biol. 94: 127-142

Hopkinson, C. S. Jr, Wetzel, R. L. (1982). In situ measurements of nutrient and oxygen fluxes in a coastal marine benthic community. Mar Ecol. Prog. Ser 10: 29-35

Jahnke, R. A., Christiansen, M. B. (1989). A free-vehicle benthic chamber instrument for sea floor studies. Deep Sea Res. 36: 625-637

James, A. (1974). The measurement of benthal respiration. Wat. Res. 8: 955-959

Kawana, K., Hoshika, A., Tanimoto, T (1987). Water quality monitoring system for oxygen consumption studies in the benthic boundary layer of the Seto inland sea. Proceedings of: 'Oceans 87. The ocean an international workplace' symposium. McNab, Halifax, p. 194-199

Keizer, P. D., Hargrave, B. T., Gordon, D. C. Jr (1989). Sediment-water exchange of dissolved nutrients at an intertidal site in the upper reaches of the Bay of Fundy, Canada. Estuaries 12: 1-12

Kelderman, P., Lindeboom, H. J., Klein, J. (1988). Light dependent sediment-water exchange of dissolved reactive phosphorus and silicon in a producing microflora mat. Hydrobiologia 159: 137-147

Kelly, J. R. (1984). Microcosms for studies of sediment-water interactions. In: Persoone, G., Jaspers, E., Claus, C. (eds.) Ecotoxicological testing for the marine environment, Vol. 2. State Univ. Ghent and Inst. Mar Scient. Res., Bredene, p. $315-330$

Kemp, W M., Boynton, W. R. (1981). External and internal factors regulating metabolic rates of an estuarine benthic community. Oecologia (Berl.) 51: 19-27

Klump, J. V., Martens, C. S. (1981). Biogeochemical cycling in an organic rich coastal marine basin - II. Nutrient sediment-water exchange processes. Geochim. Cosmochim. Acta 45: 101-121

Kuivila, K. M., Murray, J. W., Devol, A. H., Lidstrom, M. E. Reimers, C. E. (1988). Methane cycling in the sediments of Lake Washington. Limnol. Oceanogr. 33: 571-581

Laane, R. W. P. M., Gieskes, W W C., Kraay, G. W. Eversdij, A. (1985). Oxygen consumption from natural waters by photo-oxidizing processes. Neth. J. Sea Res. 19: $125-128$

Lindeboom, H. J., Sandee, A. J. J. (1989). Production and consumption of tropical seagrass fields in Eastern Indonesia measured with bell jars and microelectrodes. Neth. J. Sea Res. 23: 181-190

Lindeboom, H. J., De Klerk, H. A. J., Sandee, A. J. J. (1984). Mineralization of organic carbon on and in the sediment of Lake Grevelingen. Neth. J. Sea Res. 18: 492-510

Liu, P. L. F. (1973). Damping of water waves over porous bed. J. Hydraulics Div., Proc. Am. Soc. Civ. Eng. 99: 2263-2271

Malan, D. E. (1986). Effects of Qatar Light crude oil on adult saltmarsh crab Sesarma catenata and implications in the field: respiration, oxygen diffusion and hypoxia. S. Afr. J. mar Sci. 4: 265-275

Malan, D. E., McLachlan, A. (1985). Vertical gradients of meiofauna and bacteria in subtidal sandy sediments from two high-energy surf zones in Algoa Bay - South Africa. S. Afr. J. mar. Sci. 3: 43-53

Martens, C. S., Klump, J. V. (1980). Biogeochemical cycling in an organic-rich coastal marine basin - I. Methane sediment-water exchange processes. Geochim. Cosmochim. Acta 44: 471-490

Martin, D. C., Bella, D. A. (1971). Effect of mixing on oxygen 
uptake rate of estuarine bottom deposits. J. Wat. Pollut. Control Fed. 43: 1865-1876

McCaffrey, R. J., Myers, A. C., Davey, E., Morrison, G., Bender, M., Leudtke, N., Cullen, D., Froelich, P., Klinkhammer, G. (1980). The relation between pore water chemistry and benthic fluxes of nutrients and manganese in Narragansett Bay, Rhode Island. Limnol. Oceanogr 25 $31-44$

McLachlan, A. (1977). Studies on the psammolittoral meiofauna of Algoa Bay, South Africa. 1. Physical and chemica evaluation of the beaches. Zool. Afr 12: 15-32

McLachlan, A. (1980). The definition of sandy beaches in relation to exposure: a simple rating system. S. Afr. J. Sci. 76: $137-138$

McLachlan, A. (1983). Sandy beach ecology - a review. In: McLachlan, A, Erasmus, T (eds.) Sandy beaches as ecosystems. Junk. The Hague, p. 321-380

McLachlan, A., Cockcroft, A. C., Malan, D. E. (1984). Benthic faunal response to a high energy gradient. Mar. Ecol. Prog. Ser 16: 51-63

Murphy, R. C., Kremer, J. M. (1985). Bivalve contribution to benthic metabolism in a California lagoon. Estuaries 8 $330-341$

Murray, L., Wetzel, R. L. (1987). Oxygen production and consumption associated with the major autotrophic components in two temperate seagrass communities. Mar. Ecol. Prog. Ser. 38: 231-239

Nixon, S. W., Kelly, J. R., Furnas, B. N., Oviatt, C. A, Hale, S. S. (1980). Phosphorus regeneration and the metabolism of coastal marine bottom communities. In: Tenore, K. R. Coull, B. C. (eds.) Marine benthic dynamics. University of South Carolina Press, Columbia, p. 219-242

Nixon, S. W., Oviatt, C. A., Hale, S. S. (1976). Nitrogen regeneration and the metabolism of coastal marine bottom communities. In: Anderson, J. M., MacFadyed, A. (eds.) Proc. 17th Symposium, British Ecological Soc. Blackwell Scientific Publication, London, p. 269-283

Olah, J., Sinha, V R. P., Ayyappan, S., Purushothanan, C. S., Radheyshyam, S. (1987). Sediment oxygen consumption in tropical undrainable fish ponds. Int. Revue ges. Hydrobiol. 72: 297-305

Oviatt, C. A., Pilson, M. E. Q., Nixon, S. W., Frithsen, J. B., Rudnick, D. T., Kelly, J. R., Grassle, J. F., Grassle, J P. (1984). Recovery of a polluted estuarine system: a mesocosm experiment. Mar Ecol. Prog. Ser. 16: 203-217

Pamatruat, M. M. (1968). Ecology and metabolism of a benthic community on an intertidal sandflat. Int. Revue ges. Hydrobiol. 53: 211-298

Pamatmat, M. M. (1971). Oxygen consumption by the seabed. IV. Shipboard and laboratory experiments. Limnol. Oceanogr. 16: 536-550

Panatmat, M. M. (1977). Benthic community metabolism: a review and assessment of present status and outlook. In: Coull, B. C. (ed.) Ecology of marine benthos. Univ. of South Carolina Press, Columbia, p. 89-111

Pamatmat, M. M., Banse, K. (1969). Oxygen consumption by the seabed. II. In situ measurements to a depth of $180 \mathrm{~m}$. Limnol. Oceanogr. 14: 250-259

Pamatmat, M. M., Fenton, D. (1968). An instrument for measuring subtidal benthic metabolism in situ. Limnol. Oceanogr. 13: 537-540

Patching, J. W., Raine, R. C. I (1983). Benthic metabolısm and the supply of organic material to the sea-bed. In. MacDonald, A. G., Priede, I. G. (eds.) Experimental biology at sea. Academic Press, New York, p. 311-345

Pearson, M. P., Burns, M. D., Spencer Davies. P. (1984). An underwater respirometer and programmable data logger for in situ energy budget studies. J. exp. mar. Biol. Ecol. 74 231-239

Pregnall, A. M., Miller, S. L. (1988). Flux of ammonium from surf-zone and nearshore sediments in Nahant Bay, Massachusetts, USA in relation to free-living Pilayella littoralis. Mar. Ecol. Prog. Ser 50: 161-167

Propp, M. V (1977). Exchange of energy, nitrogen and phosphorus between water, bottom and ice in a near-shore ecosystem of the Sea of Japan. Helgoländer wiss. Meeresunters. 30: 598-610

Propp, M. V., Tarasoff, V G., Cherbadgi, I. I., Lootzik, N. V (1980). Benthic-pelagic oxygen and nutrient exchange in a coastal region of the sea of Japan. In: Tenore, K. R., Coull, B. C. (eds.) Marine benthic dynamics. Univ. of South Carolina Press, Columbia, p. 265-284

Putnam, J. A. (1949). Loss of wave energy due to percolation in a permeable sea bottom. Trans. Am. Geophys. Un. 30: 349-356

Putnam, J. A., Johson, J. (1949). The dissipation of wave energy by bottom friction. Trans. Am. Geophys. Un. 30: $67-74$

Riedl, R. N., Huang, N., Machan, R. (1972). The subtidal pump: a mechanism of interstitial water exchange by wave action. Mar. Biol. 13: 210-221

Rizzo, W. M., Wetzel, R. L. (1985). Intertidal and shoal benthic community metabolism in a temperate estuary: studies of spatial and temporal scales of variability. Estuaries 8: 342-351

Rowe, G. T., Clifford, C. H., Smith, K. L. (1977). Nutrient regeneration in sediments off Cap Blanc, Spanish Sahara. Deep Sea Res. 24: 57-63

Rutgers van der Loeff, M. M. (1981). Wave effects on sediment-water exchange in a submerged sand bed. Neth. J. Sea Res. 15: 100-112

Rutgers van der Loeff, M. M., Anderson, L. G., Hall, P. O. J., Iverfeldt, A., Josefson, A. B., Sundby, B., Westerlund, S. F. G. (1984). The asphyxiation technique: an approach to distinguishing between molecular diffusion and biologically mediated transport at the sediment-water interface. Limnol. Oceanogr 29: 675-686

Rutgers van der Loeff, M. M., Van Es, F. B., Helder, W., De Vries, R. T P. (1981). Sediment water exchanges of nutrient and oxygen on tidal flats in the Ems-Dollard Estuary. Neth. J. Sea Res. 15: 113-129

Schippel, F. A., Bagander, L. E., Hallberg, R. O. (1973). An apparatus for subaquatic in situ measurements of sediment dynamics. Stockholm Contrib. Geol. 24: 7-16

Smith, K. L. Jr (1974). Oxygen demands of San Diego through sediments: an in situ study. Limnol. Oceanogr 19: 939-944

Smith, K. L. Jr, Baldwin, R. J. (1984). Seasonal fluctuations in deep-sea sediment community oxygen consumption: central and eastern North Pacific. Nature, Lond. 307: 624-626

Smith, K. L. Jr, Burns, K. A., Teal, J. M. (1972). In situ respiration of benthic communities in Castle Harbour, Bermuda. Mar Biol. 12: 196-199

Smith, K. L. Jr, Teal, J. (1973). Deep-sea benthic community respiration: an in situ study at $1850 \mathrm{~m}$. Science 179 282-283

Snodgrass, W. J., Fay, L. A. (1987). Values of sediment oxygen demand measured in the central basin of Lake Erie, 1979 J. Great Lakes Res. 13: 724-730

Steele, J. H, Munro, A. L. S., Giese, G. S. (1970). Environmental factors controlling the epipsammic flora on beach and sublittoral sands. J. mar biol. Ass. U.K. 50: 907-918

Sundby, B., Anderson, L. G., Hall, O. J., Iverfeldt, A., Rutgers van der Loeff, M. M. Westerlund, F. G. (1986). The effect of oxygen on release and uptake of cobalt, manganese, 
iron and phosphate at the sediment-water interface. Geochim. Cosmochim. Acta 50: 1281-1288

Swart, D. H. (1983). Physical aspects of sandy beaches - a review. In: McLachlan, A., Erasmus, $T$ (eds.) Sandy beaches as ecosystems. Junk, The Hague, p. 5-44

Swart, D. H. Crowley, J. B. (1983). Wave-generated water flow through a porous sea bed. In: McLachlan, A., Erasmus, T. (eds.) Sandy beaches as ecosystems. Junk. The Hague, p. 177-189

Sweerts, J. P., Rudd, J. W. M., Kelly, C. A. (1986). Metabolic activities in flocculent surface sediments and underlying sandy littoral sediments. Limnol. Oceanogr $31 \quad 330-338$

Webb, J. E., Theodor, J. (1968). Irrigation of submerged marine sands through wave action. Nature, Lond. 220: $682-683$

This article was submitted to the editor
Webb, J. E., Theodor, J. (1972). Wave-induced circulation in submerged sands. J. mar biol. Ass. U.K. 52: 903-914

Welch, H. E., Kalff, J. (1974). Benthic photosynthesis and respiration in Char Lake. J. Fish. Res. Bd Can. 31. 609-620

Westerlund, S. F. G., Anderson, L. F., Hall, P. O. J, Iverfeldt, A., Rutgers van der Loeff, M. M., Sundby, B. (1986). Benthic fluxes of cadmium, copper nickel, zinc and lead in the coastal environment. Geochim. Cosmochim. Acta 50: $1289-1296$

Yamada, H. Kayama, M. (1987). Liberation of nitrogenous compounds from bottom sediments and effect of bioturbation by small bivalve, Theora lata (Hinds). Estuar coast. Shelf Sci. 24: 539-555

Zar, J. H. (1974). Biostatistical analysis. Prentice-Hall Biological Science Series, Englewood Cliffs

Manuscript first received: October 11, 1990

Revised version accepted: March 22, 1991 